\title{
On the strategy of utilization of resources of nonferrous metals in the far eastern region
}

\author{
Gennady Arkhipov ${ }^{1 *}$ \\ ${ }^{1}$ Mining Institute of Far eastern branch of Russian Academy of Sciences, Khabarovsk, Russia.
}

\begin{abstract}
Annotation. Analysis of current status and use of lead and zinc resources in the Far Eastern region, on the territory of Primorsky region for many decades and such analysis is of practical importance for evaluation and selection of areas in this field of activity. Russia safeguarded stocks and lead and zinc resources in the long term. On the territory of the Far East region there are significant deposits of these metals, but for single resources most of them substantially less large deposits in other regions of Russia - Siberia, Altai, Ural. Significantly to support lead-zinc industry in the region is possible in case of exploration of new deposits of ores with high quality. Lead and zinc minerals industrial scale in the region undoubtedly has and can be represented by a leading geological-industrial types of fields, but there is currently little studied. You must not reforming the present state of the industry and its innovative development: need to develop intra-regional use of raw materials in the form of the final product, that will give the region's resources development of new incentives. Nonferrous metals resource potential of the region, with an effective strategy to use them can be a significant factor in changing the geopolitical significance of the far eastern part of Russia. Key words: fields, resources, lead, zinc, production, economic growth, Far East region, «Dalpolimetall»
\end{abstract}

On the territory of the Far Eastern region, the number of ore deposits identified only reaches 1200. Analysis of the level and completeness of the use of the identified natural mineral resources, taking into account their potential, naturally belongs to one of the most important places in the study of the region's economy. The analysis of the current state and use of lead and zinc resources is of practical importance for the assessment and selection of activities in this field.

Resources and production of the Far East region. Proven reserves and estimated resources of lead and zinc deposits are most often part of the same complex polymetallic deposits in association with other useful components - tin, molybdenum, tungsten, gold, silver, rare metals. Deposits containing lead and zinc resources are shown in figure and table $1[1]$.

Reserves of zinc and lead on the territory of the Republic of Sakha (Yakutia) are counted in 5 deposits and make up: zinc $C_{1}$ category - 48 thousand tons, $C_{2}-2075$ thousand tons; lead categories $\mathrm{A}+\mathrm{B}+\mathrm{C}_{1}-826$ thousand tons, $\mathrm{C}_{2}-1466$ thousand tons. There are no developed deposits. Prepared to absorb deposits Prognoz (owns the company «Prognoz-

*Corresponding author: arhipov@igd.khv.ru 
Silver», owned by Canadian company Silver Bear Resources), Verhne Menkeche (company GeoProMining), Sardana (company «Siberian nonferrous metals» of the holding «Summa», then «East-Siberian company»). Deposits of Kutinskoe and Zarnica are on standby. Prognostic resources of lead of the Republic are estimated at 800 thousand tons, zinc 2550 thousand tons.



Fig. 1. Deposits, ore districts and promising to lead and zinc zones in the Far Eastern region. Sidebar - Dalnegorskij ore district. Types of deposits: 1 - lead-zinc (with copper, silver etc.), 2 - copper-lead-zinc, 3 - tin-polymetallic, 4 - gold-silver (with lead and zinc). Areas and zones are marked by numerals [2]: I - Krestovaya, II - Beringovskaya i Chegutunskaya, III - Chaplinskaya, IV - Berelekhskij, V - Sedyan-Kuel'skaya, VI - Tas-Hayahtahskaya, VII - Taskano-Omulevskaya and Prikolymskaya, VIII - Yudomo-Majskaya, IX - Chelasino-Maltanskaya, X - AyanoShevlinskaya, XI - Chagoyanskij, XII - Kozlovo-Kronockij, XIII - Asacha-Loptkinskaya, XIV Kuril'skaya, XV - Srednesahalinskaya, XVI - Shebuninskaya, XVII - Anivskaya, XVIII -

Samarginskaya, XIX - Kolumbe-Malinovskaya, XX - Ussurijskaya, XXI - Verhneussurijskij, XXII Hankajskaya, XXIII - Dal'negorskaya, XXIV - Pos'etskaya.

There are more than 20 explored deposits of lead and zinc on the territory of Primorsky krai. Deposits Nikolaevskoe, Partizanskoe, Porfiritovaya zona, Verhnee, Yuzhnoe, Svetlyj otvod, Majminovskoe belong to «Gorno-metallurgicheskaya kompaniya «Dal'polimetall» («GMK «Dal'polimetall», «ГМК «Дальполиметалл») and are developed. Voznesenskoe 
deposit belongs to the company "RUSAL" as fluorite spar, development, and zinc ore are stored without processing (since 2013 development temporarily stopped). Most of the unallocated deposits (Arsen'evskoe, Verhnee, Silinskoe, Smirnovskoe, Shcherbakovskoe, etc.) were previously developed for the complex of components, including tin, lead, zinc, copper, etc.

The reserves of lead in the region are more than 1.5 million tons (including reserves of categories $\mathrm{A}+\mathrm{B}+\mathrm{C}_{1}-$ almost 1 million tons), zinc -2.2 million tons (categories $\mathrm{A}+\mathrm{B}+\mathrm{C}_{1}-$ about 1.5 million tons). Lead resources are estimated at 1.6 million tons, zinc -2.5 million tons.

Table 1. The main deposits of lead and zinc in the Far East region (data from VSEGEI, IAC Mineral, etc. sources)

\begin{tabular}{|c|c|c|c|c|c|}
\hline \multirow{2}{*}{ Deposit } & \multicolumn{2}{|c|}{$\begin{array}{l}\text { Reserves, thousand } \\
\text { tons } \\
\end{array}$} & \multirow{2}{*}{ Deposit } & \multicolumn{2}{|c|}{$\begin{array}{l}\text { Reserves, thousand } \\
\text { tons }\end{array}$} \\
\hline & lead & zinc & & lead & zinc \\
\hline \multicolumn{3}{|c|}{ Republic of Sakha (Yakutia) } & Porfiritovaya zona & 14 & 24 \\
\hline Arsen'evskoe & 592 & 1926 & Vtoroe Sovetskoe & 7 & 13 \\
\hline Verhnee & 145 & 35 & Dal'netaezhnoe & 7 & 11 \\
\hline Silinskoe & 143 & 174 & Avgustovskoe & 6 & 11 \\
\hline Smirnovskoe & 135 & 132 & Arsen'evskoe & 2 & 5 \\
\hline Shcherbakovskoe & 65 & 47 & Verhnij rudnik & 1 & 5 \\
\hline \multicolumn{3}{|c|}{ Primorsky krai } & Novo-Monastyrskoe & 5 & 11 \\
\hline Nikolaevskoe & 608 & 684 & Pridorozhnoe & 1 & 0,5 \\
\hline Partizanskoe & 125 & 344 & Voznesenskoe & - & 210 \\
\hline Zimnee & $140(115)$ & $206(169)$ & \multicolumn{3}{|c|}{ Khabarovsky krai } \\
\hline Krasnogorskoe & 124 & 182 & Festival'noe & 4,4 & 1,9 \\
\hline Shcherbakovskoe & $121(117)$ & $89(82)$ & Pereval'noe & 21 & - \\
\hline Smirnovskoe & $93(85)$ & $134(123)$ & Pridorozhnoe & 0,7 & 0,5 \\
\hline Fasol'noe & 92 & 111 & Dzhatonskoe & 56 & 93 \\
\hline Yuzhnoe & 88 & 87 & Nivandzhinskoe & 31 & 29 \\
\hline Vstrechnoe & 38 & 42 & \multicolumn{3}{|c|}{ Magadanskaya oblast } \\
\hline Svetlyj Otvod & 37 & 37 & Dukatskoe & 83 & 80 \\
\hline Silinskoe & $26(19)$ & $36(26)$ & Gol'covoe & 66 & 14 \\
\hline Levickoe & 26 & 35 & Mechta & 32 & 34 \\
\hline Majminovskoe & 61 & 72 & Tidid & 19 & 28 \\
\hline
\end{tabular}

Note. In brackets - the remaining reserves at the beginning of 2013 .

In the Khabarovsky Krai, lead and zinc contain deposits of the Komsomolsk tin district, the main useful component of which is tin. Ore deposits of lead and zinc - the ordinary and the poor, the deposits of reserves of these metals is small, in the processing of complex ores at the processing plant of the company "Dal'olovo" lead and zinc concentrates were allocated in the 1990s has accumulated substantial volumes of tailings, enrichment, containing over 100 to 115 thousand tons of lead and zinc.

In different geological-structural zones of the region revealed numerous small deposits and occurrences of lead and zinc: pre-explored deposits Chayatynskoe (inventory of lead 109 thousand tons and zinc - 204 thousand tons), Majskoe (5.6 thousands ton and 21 thousands ton, respectively), Ampaarynd'inskoe (96 thousand tons and 101 thousand tons), Dzhatonskoe, Detan'dzha (71 thousand tons and 73 thousand tons), Nivandzhinskoe. Within Udoma-May trough a few dozen lead-zinc stratiform type ore manifestations form Lugun-Puhanil promising area inferred resources where estimated on lead 250 thousand tons and zinc also 250 thousand tons.

In the Magadan oblast, 4 deposits are considered, the ores of which contain lead and zinc. Until the 1990s, polymetallic concentrates from these deposits were sent to the country's plants for processing. 
According to Rosgeolfond, VSEGEI, IAC Mineral, lead reserves in the Far East are accounted for in 34 deposits and amount to about 2.3 million tons (by categories $\mathrm{A}+\mathrm{B}+\mathrm{C}_{1}+\mathrm{C}_{2}$ ), zinc reserves are more than 4 million tons in 28 deposits. More than $90 \%$ of the region's reserves are concentrated in the Primorsky krai. Inferred resources of lead in the region is about 2.6 million tons, zinc - approximately 5.2 million tonnes resources of lead are 9 deposits (scale of reserves of up to 1 million tons each) and in more than two dozen small objects. For zinc, one deposit is large (more than 1 million tons), eight are medium (0.5 - 1 million tons), the rest are small.

Mining in the district DFO in recent years (2008-2017) was on the lead concentrates 1016 thousand tonns annually in concentrates zinc $-14-32$ thousand tons. Primary production provides the company «GMK «Dal'polimetall».

Mineral resource base of Russia. According to organizations of the Ministry of natural resources and ecology of the Russian Federation - Rosgeolfond, Iinformation and analytical center "Mineral", VSEGEI, in Russia there are more than 100 mostly lead and about 150 mostly zinc deposits (often these are the same deposits). Deposits containing more than 1 million tons of reserves of lead - 3, more than 1 million tons of zinc reserves 13 , they make up more than $75 \%$ of all reserves of lead and zinc of Russia, who lead amount to 19.5 million tons (categories $A+B+C_{1}+C_{2}$ ), inferred resources of about 40 million tons, for zinc -60 million tonns, inferred resources of about 110 million tonns.

A significant number of large deposits with a high content of lead and zinc is located in the Altai region - Korbalihinskoe, Zarechenskoe, Stepnoe, Zaharovskoe, Talovskoe, Rubcovskoe. Reserves of deposit Korbalihinskoe are estimated at 26 million tonns of ore, containing nearly 470 thousand tonns of lead, and 2.2 million tonns of zinc, and 330 thousand tons of copper. The mine capacity of 1.5 million tons of ore per year with the production of about 120 thousand tons of zinc concentrate and 16 thousand tons of copper is planned to be brought to full capacity by 2021 .

Deposits of Buryatia (Ozernoe, Holodninskoe and others), as well as Altai, have a high content of useful components. Since 2009, the corporation «Metals of Eastern Siberia» («Metropol» group) has been developing the Ozernoe deposit, whose reserves of $\mathrm{B}+\mathrm{C}_{1}$ categories are 1,31 million tons of lead, 6.9 million tons of zinc, and 3.9 thousand tons of silver. In 2010, the GOK with a capacity of 1 million tons of ore per year was commissioned, and it was planned to reach its design capacity in 2016, but the full - scale commissioning of the field did not take place. Delayed development and other large zinc and lead deposits (Holodninskoe, Nazarovskoe, Kyzyl-Tashtygskoe, Nojon-Tologojskoe).

Production of lead ore in Russia is about 180-240 thousand tons per year, production of lead concentrate - up to 320 thousand tons, production of refined lead - up to 110 thousand tons per year. More than $75 \%$ of Russian lead is extracted at the deposit Gorevskoe (Krasnoyarsk krai). Russia accounts for 2-3\% of world production of lead, ores and lead concentrates are exported abroad: $90 \%$ of all exports go to China, the rest - to Kazakhstan and the Republic of Korea. In Russia there are no factories for the processing of primary lead. The first domestic plant for the production of lead from the concentrates of the deposit Gorevskoe is planned to be built in Sorsk (Republic of Khakassia). The consumption of refined lead in Russia is about 16 thousand tons per year. Russia's relatively small domestic demand for lead is fully satisfied by its production of secondary raw materials. The strategy of development of non-ferrous metallurgy of Russia for 2014-2020 and until 2030 assumes growth of consumption of the refined lead in Russia no more than by $5 \%$ a year.

Production of zinc concentrates in Russian fields is of the order of 350-360 thousand tons per year. About $75 \%$ of production is in the Urals. The main production is provided by the enterprises of the Urals Mining and Metallurgical company (UMMC). The production of refined zinc is up to 250 thousand tons per year (about $3 \%$ of world production). The consumption of refined zinc in Russia is about 225 thousand tons per year. Export of zinc 
ores and concentrates from Russia is about 70-140 thousand tons. Up to 50 thousand tons of refined zinc is exported from Russia annually to the Netherlands, Turkey, Belarus, etc. Annually about 30 thousand tons of refined zinc are imported to Russia.

The global mineral resource base. According to [3], the world reserves (probable and proven reserves) of lead in 2018 are 88 million tons, production in recent years - at the level of 4.7 million tons, zinc - 230 million tons and 12.6-13.4 million tons, respectively (table 2). The world identified resources (approximately reserves of category $\mathrm{C}_{2}$ of the Russian classification) of lead are estimated at 2 billion tons, zinc-about 1.9 billion tons.

Table 2. Reserves at the beginning of 2018 and production in 2016 and 2017 of lead and zinc (million tons) by country [3]

\begin{tabular}{|l|c|c|c|l|c|c|c|}
\hline \multicolumn{4}{|c|}{ Lead } & \multicolumn{5}{c|}{ Zinc } \\
\hline \multirow{2}{*}{ Countries } & \multirow{2}{*}{ Reserves } & \multicolumn{2}{c|}{ Mine production } & \multirow{2}{*}{ Countries } & \multirow{2}{*}{ Reserves } & \multicolumn{2}{c|}{ Mine production } \\
\cline { 3 - 4 } & & $\mathbf{2 0 1 6}$ & $\mathbf{2 0 1 7}$ & & $\mathbf{2 0 1 6}$ & $\mathbf{2 0 1 7}$ \\
\hline Australia & 35 & 0.453 & 0.450 & Australia & 64 & 0.965 & 1 \\
\hline China & 17 & 2.340 & 2.400 & China & 41 & 4.800 & 5.100 \\
\hline Russia & 6.4 & 0.250 & 0.250 & Peru & 28 & 1.330 & 1.400 \\
\hline Peru & 6 & 0.314 & 0.300 & Mexico & 20 & 0.670 & 0.680 \\
\hline Mexico & 5.6 & 0.232 & 0.230 & India & 11 & 0.682 & 1.300 \\
\hline USA & 5 & 0.346 & 0.313 & USA & 9.7 & 0.805 & 0.730 \\
\hline India & 2.2 & 0.147 & 0.150 & Kazakhstan & 13 & 0.340 & 0.360 \\
\hline Bolivia & 1.6 & 0.075 & 0.079 & Canada & 5.4 & 0.322 & 0.340 \\
\hline Sweden & 1.1 & 0.079 & 0.080 & Bolivia & 4.8 & 0.490 & 0.500 \\
\hline Turkey & 0.86 & 0.076 & 0.070 & Sweden & 3.8 & 0.257 & 0.260 \\
\hline Other countries & 7 & 0.400 & 0.390 & Other countries & 33 & 1.890 & 1.520
\end{tabular}

China is the world's leading producer of lead and zinc. Then follow Australia, USA, Peru, Mexico. They jointly provide $70 \%$ of the world's lead production and $75 \%$ of zinc in concentrates. The Republic of Korea is a major producer of lead - about 500 thousand tons/year. Over the past decade, zinc production in the world has increased by $40 \%$, the most significant growth occurred in Asia. There are about 15 companies in the world producing lead in concentrates in the amount of 10-260 thousand tons per year and more than 20 companies producing zinc concentrates in the amount of 40-740 thousand tons per year.

Conjuncture. The market of lead and zinc, as well as the entire mineral market, is subject to constant fluctuations. According to the International Lead and Zinc Study Group, world periodically there is a scarcity and a surplus of concentrates of lead and zinc on the level of several tens of thousand tons. Starting in 2012, the production volume of zinc in the world has increased steadily, on average by $2-3 \%$ annually, which was stimulated by the growing steel production in the world.

In the world market of lead and zinc there are multidirectional and quite significant price fluctuations. In the period 2001-2017, the price of lead was in the range of 476-3235 USD/t (peaked in 2007), in zinc - 886-3235 USD/t (peak 4400 dollars/t was in December 2006). In 2016, 1 ton of lead cost $\$ 1819$, in 2017 - \$2309. Zinc in 2016, was the fastest growing in the price of industrial non-ferrous metals: during January-October 2016 the price has increased by $60 \%$ (on the London stock exchange zinc was worth $2320 \mathrm{USD} / \mathrm{t}$.) The average annual price of zinc in 2016 was $2093 \mathrm{USD} / \mathrm{t}$, in $2017-2896 \mathrm{USD} / \mathrm{t}$ (the forecast of some analysts to 2018 - $3258 \mathrm{USD} / \mathrm{t}, 2019-3057 \mathrm{USD} / \mathrm{t}$.)

Experts estimate that by 2020 there are 30 possible projects, the cost of which is about 8.4 billion dollars. and what if all these projects are initiated on time, they will produce about 2.2 million tons of zinc per year by 2020. The World is secured for many decades the mining and production of concentrates of lead and zinc. 
Analysis of the use of resources in the region. Primorsky krai until the 1990s. was one of the main actors in the USSR for the extraction and processing of lead-zinc ores, despite its high cost and transport costs for deliveries to customers in western part of the country. The modern state lead-zinc industry in the region is such that it is not to be considered as a significant economic factor for the far Eastern Federal district and Primorsky krai: the gross regional product which mining is $2-2,5 \%$ (most of this income accounts for coal), in the structure of gross value added of the activity "extraction of minerals» - 1-1, $2 \%$, investments in fixed capital in the industry «mining» - 1.4-1.8 billion rubles (of the total investment of the edge of 123-140 billion rubles.).

The leading enterprise for the extraction and processing of lead-zinc ores in the region is «GMK «Dal'polimetall», which has in addition to the mines of the enterprise «Central processing factory» and «Lead plant». The company's annual ore production in previous years reached 955 thousand tons, including at the Nikolayevsky mine up to 500 thousand tons. The processing factory has an actual annual capacity of more than 700 thousand tons of ore (project 1200 thousand tons) and produces lead (more than 12 thousand tons) and zinc (more than 19 thousand tons) concentrates, in passing in lead concentrate are extracted silver, bismuth, copper, in zinc concentrate - silver and cadmium. The capacity of the processing factory allows to produce at least 20 thousand tons of lead and 32 thousand tons of zinc in concentrate. The Lead plant produced lead from concentrates in the late 1990s; zinc was not produced by the plant. In the future, the reconstruction of the plant with an increase in the production capacity of lead to 78.8 thousand tons per year was expected. However, for economic reasons, the plan was not implemented and the production of lead from primary ores decreased to 1.4 thousand tons. The plant switched to the production of lead from battery scrap. In 2016, «GMK «Dal'polimetall» produced 13,765 tons of lead concentrate and 25,512 tons of zinc concentrate. Income from sales amounted to RUB 2.5 billion. In 2017, production was approximately at the same level. The company exports the entire volume of lead and zinc concentrates to the Republic of Korea, Japan and China.

The mineral resource base of «GMK «Dal'polimetall» is concentrated in the nearby territory (within $20-40 \mathrm{~km}$ from the processing factory). According to the company, the reserves of ore of categories $\mathrm{B}+\mathrm{C}_{1}+\mathrm{C}_{2}$ are about 25 million tons with an average content of $2.73 \%$ lead, zinc $-3.58 \%$, silver $-59.5 \mathrm{~g} / \mathrm{t}$. There is a possibility of increase in reserves in all fields operated by the company. Cheremshansky ore cluster with forecast resources of 26 million tons of lead-zinc-silver ores is promising.

«GMK «Dal'polimetall» characterizes its position in the industry as "an average power mining company producing up to $15 \%$ of lead and zinc in the same concentrates from their total production in Russia." The position of the company is unstable despite the not only negative, but also positive changes in the situation. This shows a comparison of production and sales of the main products in 2013 and 2014 (according to the reports of the company published on its website). Revenues for 2014 amounted to 1822 million rubles. Due to the fall of the ruble against the dollar, the increase in revenue from the sale of commodity concentrates in 2014 compared to 2013 amounted to 216,061 million rubles, but the sales price was lower than the world average. In recent years, company has been experiencing difficulties in marketing due to its high cost, as the work is carried out on worn-out and obsolete equipment, and low competitiveness of its products.

Meanwhile, according to the company's own assessment, its position and prospects in the region are the most favorable in comparison with other mining companies of the region and the region. In the area of its activity there are deposits of lead, zinc, silver, gold, tin, tungsten, boron, coal, building materials and other mineral resources. Diversification of production for the extraction and processing of these resources can provide the company with a stable and constant growth of gross product for the long term. The geographical location, natural conditions and environment of the territory in general are the most 
favorable among the subjects of the far Eastern Federal district: it is located on the coast of the sea of Japan, in the North it borders with the Khabarovsky krai - the industrial center of the Far East, in the West - with China and in the South with the DPRK, has stable relations with the Republic of Korea. The company has access to the ice-free harbor. Neighboring countries (Japan, Republic of Korea) do not have their own mineral resources base, are a stable market. China, although it has more resources of the same types of minerals, but cannot fully load the capacity of its processing enterprises, and therefore is also a market for the products of the company.

The main and decisive negative factor is the fact that «GMK «Dal'polimetall» does not have its own funds, as a result, the company cannot count on an annual sufficient profit, is not able to pay dividends to its shareholders.

Conclusions. Russia is reliably provided with reserves and resources of lead and zinc for the long term without the Far Eastern region, as production is steadily carried out in the regions with the existing infrastructure, with existing mining enterprises that claim to create Russia's leading centers for the extraction of lead and zinc. The Far Eastern region is currently in the position of a territory whose mineral raw materials (with the exception of gold and silver) do not need a region or country and are sold in nearby countries. The degree of diversification and innovation of the regional economy is not very high, having a pronounced focus on the extraction of precious minerals with a low degree of processing of other small amounts of ore resources.

In the Far Eastern region there are significant deposits of lead and zinc. Substantially support the lead-zinc sector of the region is possible in the case of exploration of new deposits with high-grade ores. The industry needs cardinal solutions for its new organization, management of a specialized and diversified holding that would take in its sphere of interests all known and promising deposits and objects of lead and zinc, including their valuation, exploration, the creation of a modern processing base (possibly based on assets «GMK «Dal'polimetall» or a new high-tech base in the Komsomolsky ore district of the Khabarovsky krai in conjunction with other industries (tin, copper, nickel, rare metal), as well as production of the final. The construction of a chemical and metallurgical production in the area of Solnechny GOK in the Khabarovsky krai to produce a wide range of products based on polymetallic ores from the Far East and Transbaikalia was reported back in 1982 [4].

In the region, due to its spatial and economic isolation, it is necessary to create new industrial sectors for it and to develop intra-regional use of raw materials, the construction of own metallurgical enterprises, and the production of final products.

\section{References}

1. G .I. Arkhipov. Mineral'niye resursy gornorudnoy promyshlennosti Dal'nego Vostoka. Strategicheskaya otsenka vozmozhnostey osvoyeniya. Khabarovsk: Institut gornogo dela DVO RAN. 820 p. (2017).

2. V. I. Sukhov., Yu. I. Bakulin., N. P. Loshak i dr. Metallogeniya Dal'nego Vostoka Rossii. Khabarovsk: Dal'nevostochnyy NII mineral'nogo syr'ya. 217 p. (2000).

3. Mineral commodity summaries 2018: U.S. Geological Survey, 200 p., https://doi.org/10.3133/70194932

4. M. E. Uskov, A. S. Mardoyan, Yu. G. Melik-Stepanov. Issues of development of ferrous and non-ferrous metallurgy in the Khabarovsk Territory. Scientific-practical conference "Problems and main directions of integrated development and placement of the productive forces of the Khabarovsk Territory until 2000". Section 6. Khabarovsk. P. 1517. (1982). 